\title{
PENGARUH KUALITAS PELAYANAN TOUR LEADER TERHADAP LOYALITAS KONSUMEN PADA TRAVEL AGENT KENCANA WISATA TANJUNG DUREN JAKARTA
}

\author{
Aggy Cariena \\ Ni Putu Eka Mahadewi \\ I Putu Sudana \\ Email : aggy_c@gmail.com \\ PS. S1 Industri Perjalanan Wisata \\ Fakultas Pariwisata UNUD
}

\begin{abstract}
The increasing amount of traveler is affecting the tourism sector. The role of tour leader is very significant to support the success of a tour. Tour leader as a front liner of the company is needed to maintain the consumer's satisfaction which is also affect the consumer's loyalty to the company. The purpose of this study is to find the effect of Service Quality toward Consumer's loyalty from Kencana Wisata Tanjung Duren Jakarta.

Data was collected by using the questionnaire. The types of data are quantitative which obtained by calculating data from the questionnaire. The method of sampling used purposive with the determination of respondents.The data method analyzed used double regression analysis techniques, double correlation, analysis of determination, T- test and F-test with significant level of 5 percent. Assisted by using data processing program SPSS ( statistical package for social science) 15.

The research result indicates that service quality of tour leader and consumer's loyalty has a positive relation partially. Simultaneously,indicates that tangible $\left(X_{1}\right)$, empathy $\left(X_{2}\right)$, reliability $\left(X_{3}\right)$, responsiveness $\left(X_{4}\right)$ and assurance $\left(X_{5}\right)$ loyalty $(Y)$ with value 0,834 which means significantly affecting consumer's at travel agent Kencana Wisata Tanjung Duren Jakarta. The writer's suggestion is Kencana Wisata management should give special attention to maintain the honest behavior and make the tour leader more trustable to boost the consumer's satisfactian which by the end can affect the consumer's loyalty to the company.
\end{abstract}

\section{Keywords: Service Quality, Tour Leader, Consumer's Loyalty, Travel Agent.}

\section{PENDAHULUAN}

Kepariwisataan dalam dunia modern pada hakekatnya merupakan suatu cara memenuhi kebutuhan manusia dalam memberi hiburan rohani dan jasmani setelah beberapa waktu bekerja serta memiliki dana untuk berwisata di dalam negeri atau berwisata ke luar negeri. Semakin meningkatnya kebutuhan orang berwisata jelas akan meningkatkan semua usaha di sektor pariwisata. Berkembangnya sektor pariwisata di suatu daerah haruslah didukung dengan berkembangnya sarana dan prasarana pariwisata. Sarana kepariwisataan yang merupakan perusahaan- perusahaan yang memberikan pelayanan kepada wisatawan, baik secara langsung maupun tidak langsung, serta kehidupannya banyak tergantung pada kedatangan wisatawan. Sarana kepariwisataan juga dapat dibagi menjadi tiga bagian, sarana pokok kepariwisataan (main tourism superstructure) sarana pokok kepariwisataan berfungsi dalam memberikan fasilitas pokok seperti travel agent, Tour operator, hotel, hostel, homestay, cottage, pension, dan sebagainya; sarana pelengkap kepariwisataan (supplementing tourism superstructure) yang termasuk ke dalam kelompok ini adalah sarana/fasilitas olah 
raga dan sarana lainnya; sarana penunjang kepariwisataan (Supporting Tourism Superstructure) yang termasuk ke dalam kelompok ini adalah : Night Club, Steam Baths, Casinos dan lain-lain (Yoeti 1996:912)

Travel agent merupakan bagian dari sarana pokok kepariwisataan, kini travel agent dapat melayani segala sesuatu yang dibutuhkan wisatawan yaitu mulai dari dokumen perjalanan, transportasi, akomodasi, makanan, asuransi, panduan jadwal perjalanan, tiket masuk wisata hingga pemandu wisata yang akan mendampingi dari awal hingga akhir perjalanan. Demi menunjang keberhasilan sebuah tour, maka sangat dibutuhkan seorang tour leader. Sesuai dengan arti katanya dalam bahasa inggris tour yang berarti wisata dan leader yang berarti pemimpin, seorang tour leader merupakan seorang yang memimpin jalannya sebuah perjalanan wisata. Pentingnya peranan yang dimiliki oleh seorang tour leader membuat keberadaannya sangat mempengaruhi jalannya sebuah tour (Yoeti,1996).

Sebagai salah satu Travel agent yang bersaing di Jakarta, Kencana Wisata juga memiliki beberapa permasalahan di berbagai divisinya. Divisi tour merupakan divisi yang cukup menjadi sorotan dalam membawa nama baik perusahaan. Maka dari itu, tour leader yang juga menjadi salah satu ujung tombak dari pencitraan perusahaan sangatlah penting peranannya dalam menentukan tingkat kepuasan yang pada akhirnya mempengaruhi loyalitas dari para konsumen.

Meningkatnya jumlah konsumen paket wisata di Travel agent, terkadang tidak menjamin meningkatnya tingkat kepuasan maupun loyalitas konsumennya. Beberapa tahun terakhir terjadi penurunan penjualan di Kencana Wisata. Penurunan ini dapat disebabkan oleh berbagai hal, dapat dikatakan kualitas pelayanan seorang tour leader menjadi salah satu penyebabnya dikarenakan keluhan terbanyak dalam divisi tour yaitu kualitas pelayanan dari tour leader yang masih kurang maksimal. Maka dari itu hal ini menarik untuk dibahas, yaitu tentang sejauh mana Kualitas pelayanan yang diberikan oleh seorang Tour Leader dapat mempengaruhi loyalitas dari konsumen di Kencana Wisata.

\section{METODE}

Penelitian ini dilakukan di Kencana Wisata yang berlokasi di Jl. Duri B no. 10 No.63, Tanjung Duren, Jakarta. Variabel bebas yang digunakan dalam penelitian memiliki lima buah variabel yang memiliki beberapa indikator yang menentukan kualitas pelayanan tour leader. Dalam penelitian ini menerapkan teori yang disebutkan Parasuraman et al, seperti dikutip dalam Fitzdimmons (1994, p.189), dalam Zeithaml dan Bitner (1996, p.118) dan dalam Goncalves (1998, p.133) sampai pada kesimpulan bahwa lima faktor yang merupakan variabel terdiri dari reliability, responsiveness, assurance (yang mencakup competence, courtesy, dan security), empathy (yang mencakup access, communication, dan understanding the customer), serta tangible.

Dalam penelitian ini, variabel bebasnya adalah loyalitas konsumen. Dalam mengukur loyalitas, Zeithaml et al (1996:38) menyatakan dengan beberapa indikator yaitu:

(1) Konsumen akan mengatakan hal yang positif tentang perusahaan kepada orang lain.

(2) Konsumen merekomendasikan perusahaan kepada orang lain yang meminta saran

(3) Konsumen mempertimbangkan bahwa perusahaan merupakan pilihan pertama dalam melakukan pembelian jasa.

(4) Konsumen melakukan lebih banyak bisnis atau pembelian dengan perusahaan beberapa tahun mendatang.

Dalam memperoleh data yang diperlukan dalam penelitian ini dipergunakan beberapa metode observasi, wawancara, kuesioner dan dokumentasi. Untuk memberikan kadar penelitian ini, data jawaban responden menggunakan skala data likert, yaitu skala pengukuran yang mengukur sikap responden terhadap jawaban pernyataan atau pertanyaan yang nantinya dapat dijumlahkan sehingga mendapatkan sebuah hasil / nilai. Untuk itu, maka setiap jawaban akan diberi 
skor, seperti misalnya: 5 = Sangat setuju; 4 $=$ Setuju; $3=$ Ragu-ragu; $2=$ Tidak Setuju; 1 $=$ Sangat tidak setuju. Instrumen penelitian yang menggunakan skala likert ini dibuat dalam bentuk pilihan ganda, dan untuk tabel tunggal, data disajikan dan diperoleh dari perhitungan SPSS (Statistic Package for Social Science), Seluruh data yang diperoleh dari kuesioner akan diolah menggunakan SPSS 15.00 .

1) Observasi yaitu pengumpulan data dengan cara mengadakan pengamatan secara langsung di Kencana Wisata, khususnya di Tour Department dan aspek yang berhubungan dengan pengaruh kualitas pelayanan Tour Leader terhadap loyalitas konsumen di travel agent Kencana Wisata Tanjung Duren Jakarta.

2) Wawancara mendalam dilakukan secara langsung dengan informan kunci di dalam perusahaan untuk mengetahui kedalaman informasi mengenai objek yang diteliti..

3) Kuesioner yang peserta tour yang menggunakan jasa Tour Leader. Dalam penelitian ini sampel ditentukan oleh peneliti berdasarkan pertimbangan masalah, tujuan, hipotesis, metode, dan instrumen penelitian, disamping pertimbangan waktu tenaga dan pembiayaan. (Malhotra, 2007). Karakteristik dari sampel penelitian ini adalah konsumen dari Travel Agent Kencana Wisata yang pernah mengikuti wisata outbond maupun inbound dan didampingi oleh Tour Leader selama perjalanannya, dan telah selesai melakukan perjalanan sehingga sudah merasakan pelayanan yang diberikan oleh tour leader, sehingga dapat dipertanyakan loyalitasnya terhadap perusahaan.

4) Dokumentasi dilakukan untuk memperoleh informasi yang relevan dengan masalah penelitian. Informasi tersebut diperoleh dari literatur, dokumen, dan laporan ilmiah baik dalam bentuk cetak maupun elektronik.

\section{PEMBAHASAN}

Karakteristik responden pada penelitian pengaruh kualitas pelayanan tour leader terhadap loyalitas konsumen di travel agent Kencana Wisata Tanjung Duren Jakarta dari total 110 responden, dapat dilihat dari beberapa kriteria yaitu: Jenis kelamin,umur, pekerjaan, dan karakteristik responden

1) Jenis Kelamin

Jumlah responden berjenis kelamin laki-laki sebanyak 68 orang (61,82 persen), dan jumlah responden berjenis kelamin perempuan sebanyak 42 orang $(38,18$ persen). Hal ini menunjukkan sebagian besar konsumenTravel agent Kencana Wisata Tanjung Duren Jakarta berjenis kelamin laki-laki.

2) Umur

Berdasarkan umur responden dapat diketahui bahwa jumlah responden yang berumur 16-25 sebanyak 26 orang (23,64 persen), jumlah responden yang berumur $26-$ 35 sebanyak 48 orang (43,64 persen), jumlah responden yang berumur 36-45 sebanyak 36 orang $(32,73$ persen), hal ini berarti sebagian besar konsumenTravel agent Kencana Wisata Tanjung Duren Jakarta berada pada rentang umur 26-35.

3) Profesi

Berdasarkan pekerjaan responden dapat diketahui bahwa jumlah responden yang berprofesi sebagai mahasiswa/pelajar sebanyak 12 orang $(10,91$ persen), jumlah responden yang berprofesi sebagai PNS sebanyak 24 orang (21,82 persen), jumlah responden yang berprofesi sebagai Pegawai Swasta sebanyak 52 orang (47,27 persen) dan jumlah responden yang berprofesi sebagai wiraswasta sebanyak 22 orang $(20,0$ persen), hal ini berarti sebagian besar konsumenTravel agent Kencana Wisata Tanjung Duren Jakarta berprofesi sebagai pegawai swasta.

Analisis deskriptif disajikan untuk memberikan informasi mengenai karakteristik variabel-variabel penelitian yaitu rata-rata dan kriteria. Adapun analisis deskriptif pada masing-masing variabel disajikan sebagai berikut.

\section{1) Tangible}

Dapat diketahui bahwa nilai total ratarata jawaban responden sebesar 3,31 dibulatkan menjadi 3, maka ini berarti secara keseluruhan konsumen di Travel agent Kencana Wisata Tanjung Duren Jakartamemberikan respon cukup setuju terhadap pernyataan mengenai variabel tangible. Indikator pertama merupakan 
indikator yang memiliki nilai skor rata-rata tertinggi yaitu sebesar 3,39 maka hal ini mengindikasikan cukup baiknya penampilan tour leader terkait kerapian dan meyakinkan konsumenTravel agent Kencana Wisata Tanjung Duren Jakarta saat operasional.

\section{2) Empathy}

Dapat diketahui bahwa nilai total ratarata jawaban responden sebesar 3,35 dibulatkan menjadi 3 maka ini berarti secara keseluruhan konsumen di Travel agent Kencana Wisata Tanjung Duren Jakarta memberikan respon cukup setuju terhadap pernyataan mengenai variabel empathy. Indikator pertama merupakan indikator yang memiliki nilai skor rata-rata tertinggi yaitu sebesar 3,56 maka hal ini mengindikasikan baiknya pelayanan Tour leader dalam hal ini mampu memahami kebutuhan dan keinginan masing-masing peserta tour.

\section{3) Reliability}

Dapat diketahui bahwa nilai total ratarata jawaban responden sebesar 3,35 dibulatkan menjadi 3 maka ini berarti secara keseluruhan konsumen di Travel agent Kencana Wisata Tanjung Duren Jakarta memberikan respon cukup setuju terhadap pernyataan mengenai variabel empathy. Indikator pertama merupakan indikator yang memiliki nilai skor rata-rata tertinggi yaitu sebesar 3,56 maka hal ini mengindikasikan baiknya pelayanan Tour leader dalam hal ini mampu memahami kebutuhan dan keinginan masing-masing peserta tour.

4) Responsiveness

Dapat diketahui bahwa nilai total ratarata jawaban responden sebesar 3,39 dibulatkan menjadi 3 maka ini berarti secara keseluruhan konsumen di Travel agent Kencana Wisata Tanjung Duren Jakarta memberikan respon cukup setuju terhadap pernyataan mengenai variabel reliability. Indikator keempat merupakan indikator yang memiliki nilai skor rata-rata tertinggi yaitu sebesar 3,89 maka hal ini mengindikasikan baiknya informasi dalam hal ini Tour Leader mampu memberikan informasi yang akurat pada konsumen diTravel agent Kencana Wisata Tanjung Duren Jakarta.

\section{5) Assurance}

Dapat diketahui bahwa nilai total ratarata jawaban responden sebesar 3,27 dibulatkan menjadi 3 maka ini berarti secara keseluruhan konsumen di Travel agent Kencana Wisata Tanjung Duren Jakarta memberikan respon cukup setuju terhadap pernyataan mengenai variabel responsiveness. Indikator kedua merupakan indikator yang memiliki nilai skor rata-rata tertinggi yaitu sebesar 3,37 maka hal ini mengindikasikan cukup baiknya pelayanan yang diberikan dalam hal ini Tour leader bersedia merespon dan mengatasi komplain peserta.

6) Loyalitas Konsumen

Dapat diketahui bahwa nilai total ratarata jawaban responden sebesar 3,23 dibulatkan menjadi 3 maka ini berarti secara keseluruhan konsumen di Travel agent Kencana Wisata Tanjung Duren Jakarta memberikan respon cukup setuju terhadap pernyataan mengenai variabel loyalitas konsumen. Indikator kedua merupakan indikator yang memiliki nilai skor rata-rata tertinggi yaitu sebesar 3,38 maka hal ini mengindikasikan cukup baiknya respon dari konsumen sehingga konsumen akan merekomendasikan Kencana Wisata kepada orang lain yang meminta saran.

Berdasarkan data dari kuesioner yang disebarkan dan diolah dengan SPSS 15.00 maka dapat diperoleh hasil sebagai berikut :

1) Analisis Regresi Linier Berganda

Berdasarkan analisis yang dilakukan dapat ditulis persamaan regresi linear berganda sebagai berikut.

$Y=\alpha+\beta_{1} X_{1}+\beta_{2} X_{2}+\beta_{3} X_{3}+\beta_{4} X_{4}+\beta_{5} X_{5}$

$Y=0,469+0,272 X_{1}+0,312 X_{2}+0,207 X_{3}$ $+0,303 X_{4}+0,124 X_{5}$

Berdasarkan persamaan regresi di atas, dapat dijelaskan bahwa variabel bebas berpengaruh positif terhadap variabel terikat, artinya peningkatan pada variabel tangible $\left(\mathrm{X}_{1}\right)$, empathy $\left(\mathrm{X}_{2}\right), \quad$ reliability $\left(\mathrm{X}_{3}\right)$, responsiveness $\left(\mathrm{X}_{4}\right)$ dan assurance $\left(\mathrm{X}_{5}\right)$ akan berdampak pada meningkatnya loyalitas konsumen (Y) di Travel agent Kencana Wisata Tanjung Duren Jakarta. 
2) Analisis Korelasi

Model Summary ${ }^{b}$

\begin{tabular}{lllll}
\hline Model & $\mathrm{R}$ & $\begin{array}{l}\mathrm{R} \\
\text { square }\end{array}$ & $\begin{array}{l}\text { Adjusted } \\
\mathrm{R} \text { Square }\end{array}$ & $\begin{array}{l}\text { Std Error } \\
\text { of the } \\
\text { Estimate }\end{array}$ \\
\hline 1 & $.834^{3}$ & .696 & .682 & 1.1718 \\
\hline
\end{tabular}

Pada tabel diatas dapat diketahui nilai koefisien korelasi secara secara simultan menghasilkan sebesar 0,834 jika disesuaikan dengan kriteria hubungan diketahui secara simultan (bersamaan) variabel tangible, empathy, reliability, responsiveness, dan assurance memiliki hubungan (korelasi) yang sangat kuat terhadap loyalitas konsumen di Travel agent Kencana Wisata Tanjung Duren Jakarta.

3) Determinasi

Melalui koerfisien determinasi, maka dapat dilihat persentase kontribusi variabel bebas yaitu Kualitas pelayanan yang terdiri dari tangible, empathy, responsiveness, responsibility, dan assurance terhadap loyalitas konsumen (Y) di Travel agent Kencana Wisata Tanjung Duren Jakarta sebesar $\mathrm{R}^{2}$ yaitu 0,679 yang berarti bahwa Kualitas pelayanan Tour Leader memberikan kontrubusi sebesar $67,9 \%$.

4) Uji F signifikansi simultan

Dari hasil data yang diperoleh, $\mathrm{F}_{\text {hitung }}$ $(47,702)>F_{\text {tabel }}(2,30)$ dengan tingkat signifikan $0,000<0,05$ maka Ho ditolak Hi diterima. Hal ini berarti secara simultan variabel tangible $\left(\mathrm{X}_{1}\right)$, empathy $\left(\mathrm{X}_{2}\right)$, reliability $\left(\mathrm{X}_{3}\right)$, responsiveness $\left(\mathrm{X}_{4}\right)$ dan assurance $\left(\mathrm{X}_{5}\right)$ berpengaruh signifikan terhadap loyalitas konsumen $(\mathrm{Y})$ di Travel agent Kencana Wisata Tanjung Duren Jakarta.

5) Uji $T$ signifikansi parsial

Uji regresi parsial (t-test) bertujuan untuk menguji signifikansi pengaruh variabel bebas kualitas pelayanan (tangible $\left(\mathrm{X}_{1}\right)$, empathy $\left(\mathrm{X}_{2}\right)$, reliability $\left(\mathrm{X}_{3}\right)$, responsiveness $\left(\mathrm{X}_{4}\right)$ dan assurance $\left(\mathrm{X}_{5}\right)$ ) terhadap loyalitas konsumen (Y) di Travel agent Kencana Wisata Tanjung Duren Jakarta.

5.1)Pengaruh kualitas pelayanan (tangible) terhadap loyalitas konsumen

Dapat dijelaskan bahwa $t_{\text {hitung }}(2,578)>t_{\text {tabel }}$ $(1,658)$ dengan tingkat signifikansi $(0,011)$ $<\alpha \quad(0,05)$, sehingga $\mathrm{H}_{0}$ ditolak dan $\mathrm{H}_{1}$ diterima yang berarti bahwa variabel tangible $\left(\mathrm{X}_{1}\right)$ secara parsial berpengaruh signifikan terhadap loyalitas konsumen $(\mathrm{Y})$ di Travel agent Kencana Wisata Tanjung Duren Jakarta.

5.2) Pengaruh kualitas pelayanan (empathy) terhadap loyalitas konsumen

Dapat dijelaskan bahwa $t_{\text {hitung }}(3,076)>t_{\text {tabel }}$ $(1,658)$ dengan tingkat signifikansi $(0,003)$ $<\alpha(0,05)$, sehingga $\mathrm{H}_{0}$ ditolak dan $\mathrm{H}_{1}$ diterima yang berarti bahwa variabel empathy $\left(\mathrm{X}_{2}\right)$ secara parsial berpengaruh signifikan terhadap loyalitas konsumen $(\mathrm{Y})$ di Travel agent Kencana Wisata Tanjung Duren Jakarta.

5.3) Pengaruh kualitas pelayanan (reliability) terhadap loyalitas konsumen

Dapat dijelaskan bahwa $t_{\text {hitung }}(3,087)>t_{\text {tabel }}$ $(1,658)$ dengan tingkat signifikansi $(0,003)$ $<\alpha \quad(0,05)$, sehingga $\mathrm{H}_{0}$ ditolak dan $\mathrm{H}_{1}$ diterima yang berarti bahwa variabel reliability $\left(\mathrm{X}_{3}\right)$ secara parsial berpengaruh signifikan terhadap loyalitaskonsumen (Y) di Travel agent Kencana Wisata Tanjung Duren Jakarta.

5.4) Pengaruh kualitas pelayanan (responsiveness) terhadap loyalitas konsumen

Dapat dijelaskan bahwa $t_{\text {hitung }}(3,209)>t_{\text {tabel }}$ $(1,658)$ dengan tingkat signifikansi $(0,002)$ $<\alpha \quad(0,05)$, sehingga $\mathrm{H}_{0}$ ditolak dan $\mathrm{H}_{1}$ diterima yang berarti bahwa variabel responsiveness $\left(\mathrm{X}_{4}\right)$ secara parsial berpengaruh signifikan terhadap loyalitaskonsumen (Y) di Travel agent Kencana Wisata Tanjung Duren Jakarta.

5.5)Pengaruh kualitas pelayanan (assurance) terhadap loyalitas konsumen

Dapat dijelaskan bahwa $t_{\text {hitung }}(2,000)>t_{\text {tabel }}$ $(1,658)$ dengan tingkat signifikansi $(0,048)$ $<\alpha(0,05)$, sehingga $\mathrm{H}_{0}$ ditolak dan $\mathrm{H}_{1}$ diterima yang berarti bahwa variabel assurance $\left(\mathrm{X}_{5}\right)$ secara parsial berpengaruh signifikan terhadap loyalitaskonsumen (Y) di Travel agent Kencana Wisata Tanjung Duren Jakarta. 


\section{SIMPULAN DAN SARAN \\ Simpulan}

Berdasarkan hasil pembahasan diatas, secara parsial dan simultan. terdapat pengaruh positif dan signifikan antara kualitas pelayanan terhadap kepuasan konsumen, artinya peningkatan kualitas pelayanan (tangible, empathy, reliability, responsiveness, dan assurance) akan berdampak pada meningkatnya loyalitas konsumen di Travel agent Kencana Wisata Tanjung Duren Jakarta. Variabel kualitas pelayanan (tangible, empathy, reliability, responsiveness, dan assurance) juga memiliki korelasi (hubungan) yang sangat kuat terhadap loyalitas konsumen di Travel agent Kencana Wisata Tanjung Duren Jakarta.

\section{Saran}

Berdasarkan simpulan di atas, maka adapun hal-hal yang dapat disarankan adalah sebagai berikut.

1) Secara akademis diharapkan meningkatnya kualitas sumber daya manusia yang akan bekerja di industri perjalanan wisata dengan mengetahui pentingnya kualitas pelayanan, khususnya tour leader yang dapat mempengaruhi loyalitas konsumen di sebuah perusahaan.
2) Secara praktis diharapkan manajemen Travel agent Kencana Wisata Tanjung Duren Jakarta untuk memperhatikan kelengkapan, pemberian informasi, kecepatan pelayanan, kesigapan serta kejujuran tour leader sehingga dapat memberikan kualitas pelayanan yang terbaik dan pada akhirnya dapat meningkatkan loyalitas konsumen terhadap perusahaan

\section{DAFTAR PUSTAKA}

Fitzsimmons. 1994. Service Management for competitive advantage. New York : McGraw-Hill College.

Goncalves, Karen.P. 1998. Service marketing A Strategy Approach. New Jersey: Prentice Hall.

Malhotra, Naresh, 2007. Marketing Research : an applied orientation, pearson education, inc., fifth edition. New Jersey : Delmar Publisher.

Yoeti, O.A. 1996. Tours and Travel management. Jakarta : Pradnya Paramitha.

Zeitaml, V.Z., Bitner, M.J. 1996. Service marketing. New York : McGraw-Hill Inc. 